The Geneva Papers on Risk and Insurance, 23 (No. 89, October 1998), 519-529

\title{
The Economic Role of the Insurance Sector in the Risk Transfer - Capital Market Nexus
}

\author{
by Gerry Dickinson*
}

\section{Introduction}

The private insurance sector plays a central role in a modern economic system. In this paper its two most important intermediary roles are discussed: (a) as a mechanism for risk transfer; and (b) as a means of mobilising saving and developing the capital market. Although life insurance companies and non-life insurance companies perform both roles, it is non-life insurance companies that have the more significant role as a risk intermediary, while life insurance is more important as an investment intermediary. Moreover, in the context of the economic system as a whole, these two roles are complementary. On the one hand, in order to assume risks insurance companies need to hold capital; on the other hand, the mobilisation of long-term savings and its subsequent investment provides a flow of new capital which is available to help underpin the risk absorption role.

\section{The role of insurance sector as a risk intermediary}

\subsection{Outline of the risk transfer mechanism}

To supply insurance in a competitive marketplace, insurance companies must be able to price insurable risks in order to create a sustainable supply. This means that they have to collect information to allow them to estimate the probabilities of its losses (claims) and their severity. It is a practice in many markets for the insurance industry to pool information, a practice sometimes encouraged by governments, providing it does not result

* Professor and Director, Centre for Insurance \& Investment Studies, City University Business School, London. 
in restrictions on price competition. This pooling of information can be shown to be mutually beneficial to all insurance companies, even in a competitive market. Failure of an insurance company to price insurable risks adequately in a competitive market will tend to lead to financial problems. If the pricing of the risk is too low, then the insurance company will over time become unprofitable, since its claims payments will exceed those assumed in its pricing and can lead to insolvency. Moreover, an insurance company which underprices insurance can weaken other companies in the market that are tempted to follow suit in order to maintain their market share. On the other hand, if an insurance company sets its prices too high, this will mean that these prices cannot be sustained in a competitive market since other insurance companies will charge more appropriate prices and hence the insurance company will not attract business. Fair or discriminatory pricing is the key issue in the efficient supply of private insurance.

This commercial necessity for insurance companies to be able to price different risks contrasts with the social insurance supplied by the state. In social insurance, there is no need to have a pricing system which discriminates between the risks, since the purchase of insurance is compulsory and the state is a monopoly supplier. In social insurance, crosssubsidisation exists, with those having lower likelihood of loss subsidising those that have a higher likelihood. In effect there is an income redistribution in social insurance programmes and since this income redistribution is often not well targeted, it is less optional than income redistribution through the tax system.

Moreover, private insurance contracts have to be legally enforceable and hence the legal system must be sufficiently clear so that any legal disputes can be resolved fairly. Failure to have an adequate legal system means that individuals or companies can be unprotected, especially in relation to claim payments since insurance companies usually collect premiums at the beginning of the insurance contract while claim payments are paid later. Consumers which have a bad experience in not having a claim settled fairly, because of a failure in the legal system or otherwise, will not purchase insurance in the future and hence the insurance market will not grow.

One major advantage of insurance is that insurance companies can reduce the level of risk through portfolio diversification i.e. the law of large numbers. By selling insurance to a large number of consumers, where the causes of loss are to a large degree independent of each other, the risk that the insurance company faces is less than the sum of risks of individual risks faced by these consumers.

A benefit of the risk transfer mechanism is the fact that insurance companies have access through reinsurance to a network of other insurers. This risk sharing network is an important part of the insurance mechanism, especially for large potential losses. It is through reinsurance that large potential losses can be spread across the international economy. Essentially, the mechanism of reinsurance is one of accessing the capital of other insurance companies. When an insurance company buys reinsurance, the reinsurance premium paid is in effect a payment for the use of the capital of the reinsurance supplier. Due to reinsurance, therefore, the capital of a national insurance market is extended internationally, since it allows access to the capital base to all those in the global reinsurance network. The international reinsurance market itself also has access additional capital from the global capital markets to absorb very large potential losses. This risk transfer network supported eventually by global capital markets is depicted in Figure 1. 
Over time there has been a process of risk disintermediation taking place, with large buyers of insurance bypassing the insurance markets and accessing the reinsurance markets directly through their own insurance companies (i.e. captive insurance companies). More recently, a few very large corporations with good credit ratings have bypassed the insurance and reinsurance markets altogether and financed extremely large potential losses by setting up arrangements directly with the capital markets by issuing contingent debt and equity instruments

As the Figure 1 also shows there are financial risks, such adverse movements in foreign exchange rates, commodity prices, interest rates etc., which corporations can reduce through hedging with financial derivatives. The hedging of these financial risks through the purchase of financial derivatives is a complementary process to the transfer of insurable risks through the purchase of insurance. In an increasing number of corporations, decisions on how much of the insurable or financial risks they face are retained in the group and how much is transferred through insurance or hedged through financial derivatives are considered together. It can be shown theoretically that it is suboptional for the corporation to decide on the level of deductible on its insurable risks and the level of risk retention on its financial risks (e.g. strike prices on option contracts) separately: they must be determined jointly (see Dickinson (1997)).

The development of financial markets has also benefited the risk transfer role of insurance and reinsurance companies to a degree. To the extent that the use of currency,

Figure 1: Risk Transfer Network

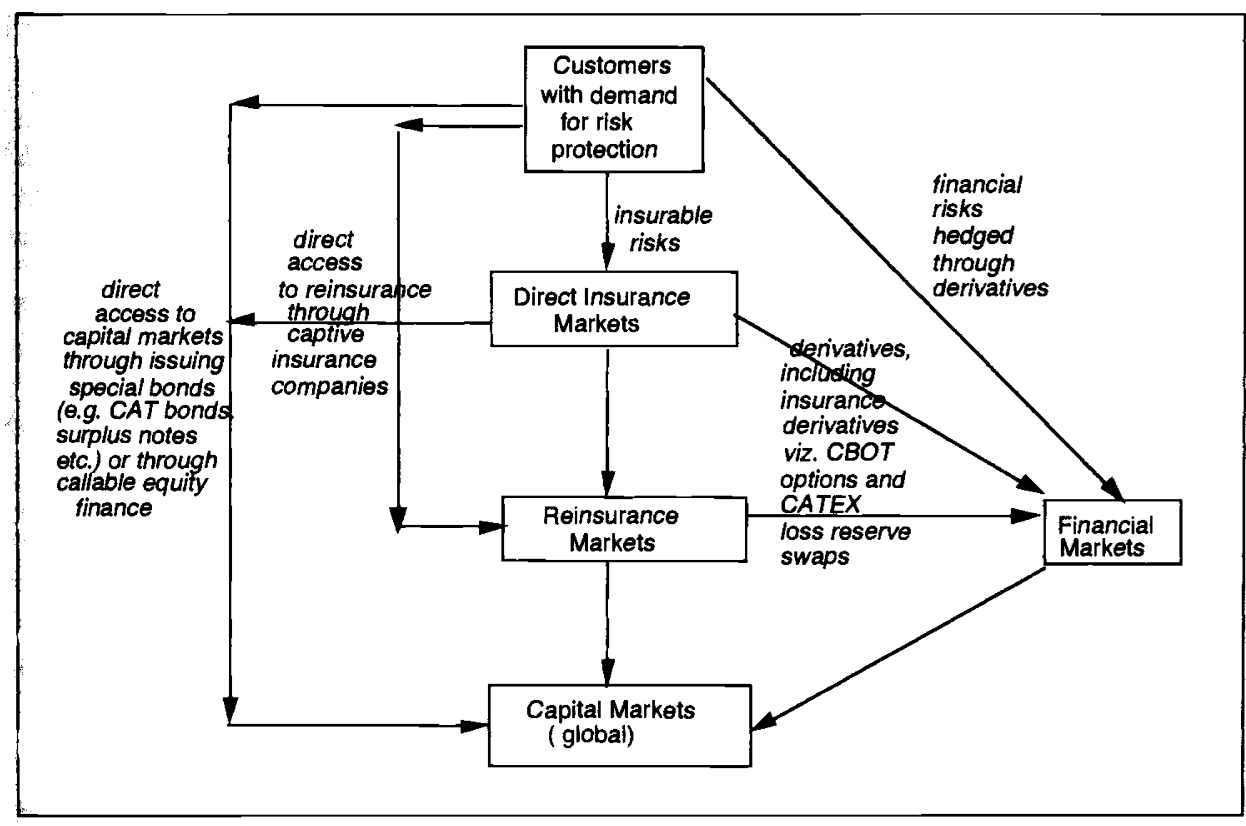


interest rate and equity market derivatives allow an insurance company to more optimally risk manage its assets and liabilities, this will indirectly assist in its wider risk transfer role since it will reduce the level of precautionary capital that the insurance company needs to hold and reduce its cost of capital. Moreover, with the development of insurance derivatives there is a more direct support in the risk transfer process. The Chicago Board of Trade catastrophe property insurance options provide a limited risk reduction facility for managing property claims, while the loss reserve swap market developed by CATEX permits a more optimal portfolio diversification of loss reserves ( outstanding claims provisions). These insurance derivative markets are still small, but they are likely to grow, especially the loss reserve swap markets since they have an international market potential. It is interesting to note that there are no derivatives based on the price of a class of insurance or reinsurance or on the price of underlying insurable losses; this is because no suitable price indices have yet been constructed. If such derivatives were to be created they would have a more significant effect on the risk transfer mechanism, both as an complement to and as a substitute for insurance and reinsurance.

\subsection{Economic benefits of the risk transfer mechanism}

Transferring insurable risks onto an efficient insurance markets has potential benefits in the following way. When operating in competitive markets, industrial, commercial and trading enterprises have to take business risks in order to make profit. By being able to transfer some of the risks associated with their commercial and investment decisions, the decision-taking process is itself less risky. Hence, decision-makers being faced with less uncertainty will be more prepared to undertake more adventurous and potentially more profitable activities. Thus, the existence of insurance markets allows the economy as a whole to be more enterprising and to undertake longer term capital expenditure decisions which might not have been undertaken or delayed in their introduction.

Insurance markets also provide protection against some of the risks associated with international trade, e.g. damage or loss of goods in transit and credit risks associated with the non-payment by foreign customers. Cargo marine insurance and international credit insurance thus helps to facilitate the flow of international trade. Moreover, in some insurance markets there is also cover against overseas investments being expropriated by foreign governments. The existence of political risks insurance encourages the flow of international direct investment. Economic experience shows that world economic growth depends on the growth of international trade and international investment. By assisting their flow, insurance and reinsurance markets indirectly contribute to the growth of the global economy.

The risk transfer facility provided by insurance companies can be viewed in terms of the efficient use of capital. Industrial, commercial and trading enterprises would need to have more precautionary capital to run their enterprises, if there were no insurance markets to transfer these risks onto. In effect insurance companies supply contingent equity capital to industrial and commercial enterprises. This means that across the economy as a whole less equity capital is needed to support commercial and trading activities.

One potential problem with insurance is moral hazard, i.e. individuals and companies having bought insurance may be less careful and hence may not protect their insured 
assets and may be more likely cause financial loss to others, because the insurance company will pay the cost rather than themselves (see Shavell (1979)). If behaviour is affected by insurance in this way then insurance would result in a cost to the wider economic and society. However, insurance companies are aware of this problem, since higher than expected losses affect them financially in the first instance. Insurance companies seek to reduce moral hazard through insurance contract design, such as by requiring customers to share some of the risk (e.g. deductibles) and by creating incentives (e.g. offering reduced premiums in future if loss experience is better than expected).

\subsection{Risk management services}

Insurance companies, reinsurance companies and insurance brokers also provide loss prevention, safety and risk management advice and services to their customers. These loss prevention and safety services are beneficial to enterprises and individuals, even when they have adequate levels of insurance. An example of this is a fire that damages the production facility of a manufacturing company. The insurance company may pay for the restoration of the production facility through property insurance and some of the loss of profits through business interruption insurance, but the manufacturing company will still lose financially because it is likely to lose some of their customers as they move to other suppliers while its production is out of action. In addition, there are also important benefits to the wider economic and social system from these loss prevention and safety management services. If effective prevention systems can be put in place to reduce the potential damage to individuals, to physical assets and infrastructure or to the geo-physical environment caused by human error or carelessness or by natural catastrophes, then economic and human costs to a nation can be avoided. Insurance companies have a inherent incentive, at least in the short term, to encourage loss prevention and safety practices, since they will benefit from having lower claim payments on their insurance contracts.

\subsection{Risk support for banks within the financial system}

Insurance companies also provide some risk support for commercial and mortgage banks in their role as financial intermediaries. One area of support is the risk transfer facilities provided by credit insurance. From an economic perspective, credit insurance is a factor input into the supply of banking lending products. And if fair pricing exists, credit insurance can be shown to be more efficient than the alternative which would be for banks to hold more precautionary capital to absorb these risks themselves. Just as in a nonbanking corporation, this cost efficiency arises because insurance is a form of contingent capital, a cost efficiency that is supported by the fact that the insurance sector can transfer credit risk, particularly systematic or non-diversifiable risk, across national and international reinsurance networks.

During the last decade there has been another form of risk transfer support which the insurance sector has begun to supply to the commercial banking system. This is in their interest rate and liquidity risk management. In contrast to credit risk, this risk transfer support is mainly supplied by life insurers rather than non-life insurers. Due to competitive pressure in lending markets, banks are required to mismatch their maturity structures of their assets and liabilities, in particular by lengthening asset maturities and assuming more 
fixed rate lending, including leasing, than their liabilities structure would normally permit. Hence through their investment portfolios life insurance companies assist banks to manage their interest rate risks, either directly through purchasing long dated, fixed-rate debt issued through the capital markets or through direct placements, or indirectly by taking positions in swap and in other financial markets.

In addition, when commercial and mortgage banks have sought to increase the liquidity within their asset portfolios by securitizing their non-tradeable loans, the bonds issued from this process have often been purchased by life insurance companies.

By assisting banks to hedge their interest rate risks and to improve their liquidity through securitization in the face of changing demands being placed upon them by their corporate and personal borrowers, insurance companies help improve the efficiency of the banking system. How are life insurance companies able to do this? Fundamentally the reason that they can confer this benefit to the banking system stems from the long-term nature of their asset/liability positions. Since life insurers have long-term investment horizons and have a low precautionary liquidity preference, they can confer some of those attributes, at a cost, to banks. Because of these longer time horizons, they can more easily accommodate any temporary disequilibrium in their asset/liabilities positions than banks can.

\section{The role of insurance sector as a savings and investment intermediary}

Insurance companies stimulate private sector saving in a variety of ways. Firstly, all insurance contracts, whether life or non-life (property and casualty), give rise to some form of private saving. This arises primarily from the fact that insurance premiums are paid in advance by customers, while claims and policy settlements paid back to consumers at a later date, after covering operating and marketing costs. This time lag between the receipt of premiums and the payments back to consumers varies between different classes of insurance. Clearly, the time lag is longer for life insurance contracts than for non-life insurance contracts, and hence the accumulation of investable funds is higher. In addition, the plough back of investment returns earned on the accumulation of these invested funds by insurance companies also contributes to the total level of saving.

Secondly, life insurance contracts, and especially endowment policies and those concerned with pension provision, have a more significant saving element. This arises not just from the fact that premiums are paid by customers in advance but because the insurance contracts themselves entail a deliberate financial commitment by the consumer to save for the future. Hence saving here is of a different kind: it represents a voluntary saving as opposed to an involuntary saving from the pricing practice of paying insurance premiums in advance. Again, the plough back of investment income earned on the accumulation of these invested funds also contributes to the saving process.

Thirdly, the capital supplied to insurance companies by shareholders is part of the saving process. But it is only that part of shareholder capital that is set aside to cover large potential claim payments or to fund the future growth of business that represents saving, thus excluding the capital that is used to set up and run the operations of the insurance company. 


\subsection{Mobilisation of saving}

Life insurance has historically been an important method through which individuals with relatively low incomes have been able to save and invest effectively for the longer term. By designing relatively simple life insurance and savings contracts, which can be purchased in small amounts on a regular basis, insurance companies have been able to accumulate large amounts of money from across a large proportion of the population. By pooling these savings from many small investors into large accumulations of investable funds, insurance companies have been able to invest not only in a wider range of investments than individuals would have been able to invest in directly themselves but have also been able to invest in larger scale and more risky investment opportunities which will be more beneficial to the economy. In addition, because in life insurance there is a regular or contractual nature to the payment of premiums by consumers, the level and stability of personal saving is increased, compared to what would be the case if the payment system is more discretionary. This contractual nature of the premium payment system in life insurance has been reinforced by insurance companies developing good marketing strategies in order to encourage individuals to save. There is no doubt that the efforts of insurance companies in creating effective sales and marketing techniques, despite the occasional criticisms of pressure selling, have played a key role in the growth of the life insurance business, and hence indirectly stimulated the level of long term saving within the economy as a whole.

\subsection{Investment and the development of capital markets}

It is through the investment of the premiums paid by policyholders (and also the investment of shareholder funds) that the transmission of saving is fed through into the wider economy. The mechanism through which this transmission takes place is the capital market. The range of investments in which an insurance company can invest its funds within a given economy will depend of the degree of development of the local capital market. Savings mobilised and invested in the capital market by insurance companies clearly acts as an important stimulus to the growth of the capital market itself. However the relationship between the level of saving generated through life insurance and private pension contracts and the development of a domestic capital market is a two-way process. This is because life insurance and private pension contracts usually involve a voluntary decision to save on the part of customers. Customers will not wish to save through these contracts if the investment opportunities that are available to insurance companies in the capital market are not attractive. Hence there is a dynamic interaction process at work, with the development of saving through life insurance and the development of the capital market both evolving together, with one assisting the other.

It is worth noting here that if there are onerous regulations placed on the investment policies of insurance company funds by insurance legislation, even though they may have the sound intention of reducing the risk of insurance company insolvency, they can inhibit both the development of the life insurance industry and the capital market. Hence there should be co-ordination between the insurance regulatory authority and those drafting insurance legislation and other government departments charged with this wider responsibility of seeking to develop the local capital market. 
In addition, life insurance companies also play a risk absorption role in the capital market as underwriters of new equity and bond issues. By guaranteeing the placement of issues and placing a floor on the issue price, this encourages the supply of new issues onto the capital market.

\subsection{Economic benefits of the saving and investment process}

What are the wider economic benefits that derive from the stimulation of private sector saving and its subsequent investment in the capital market within a given economy? Firstly, these savings can be made available, either in the form of equity or debt capital, to manufacturing, agricultural, energy, trading enterprises etc., in the private sector. New companies can be set up and finance is available for existing companies to increase their level of capital expenditure in new plant, equipment etc. Moreover, particularly for life insurance, since the time horizons for investment are long-term, these savings can be tied up for a long time and hence can be made available for capital expenditure decisions that only will produce profits in the future. This investment activity of life insurance complements the lending practices of the banking system, since banks can only provide short-term finance to manufacturing and other enterprises, because of the short-term nature of their deposits.

These long-term savings generated by life insurance companies can also be made available to government to allow to fund improvements in the infrastructure, since this infrastructure investment is important, especially in emerging economies, not only to underpin the growth of domestic private sector companies but also to encourage foreign companies to enter the local economy.

These capital expenditure decisions, both by the private sector and by the government, should lead to increases in the level of employment and increases in the standard of living across the economy. Moreover, as the productive base of the nation is increased, the export potential of the country also increases, as well as allowing the country to supply more of the goods that it currently imports from abroad. Not only is the balance of payments and foreign exchange holdings improved, but the domestic exchange rate is also strengthened.

The stimulation of greater saving also has short-term economic benefits. If individuals can be persuaded to save more, then by definition they will be consuming less. This reduced consumption will help to lower any inflationary pressures that might exist within the economy. This inflation-reducing benefit will clearly be greater within an economy where consumption is tending to squeeze out potential capital expenditure.

In addition, there is a wider psychological benefit from encouraging the growth of domestic saving within a country. This is because a country by generating its own domestic saving will have less reliance on inward foreign investment or, in other words, have less reliance on the savings of foreigners, since all inward foreign investment ultimately derives from the long term savings of foreigners. Even though the world economy today is international in nature, there needs to be an adequate level of domestic saving to finance domestic capital expenditure. If domestic saving is too little, then the ownership of the economy will gradually tend, directly or indirectly, to fall more and more under foreign 
Figure 2: Saving through insurance in its macro-economic context

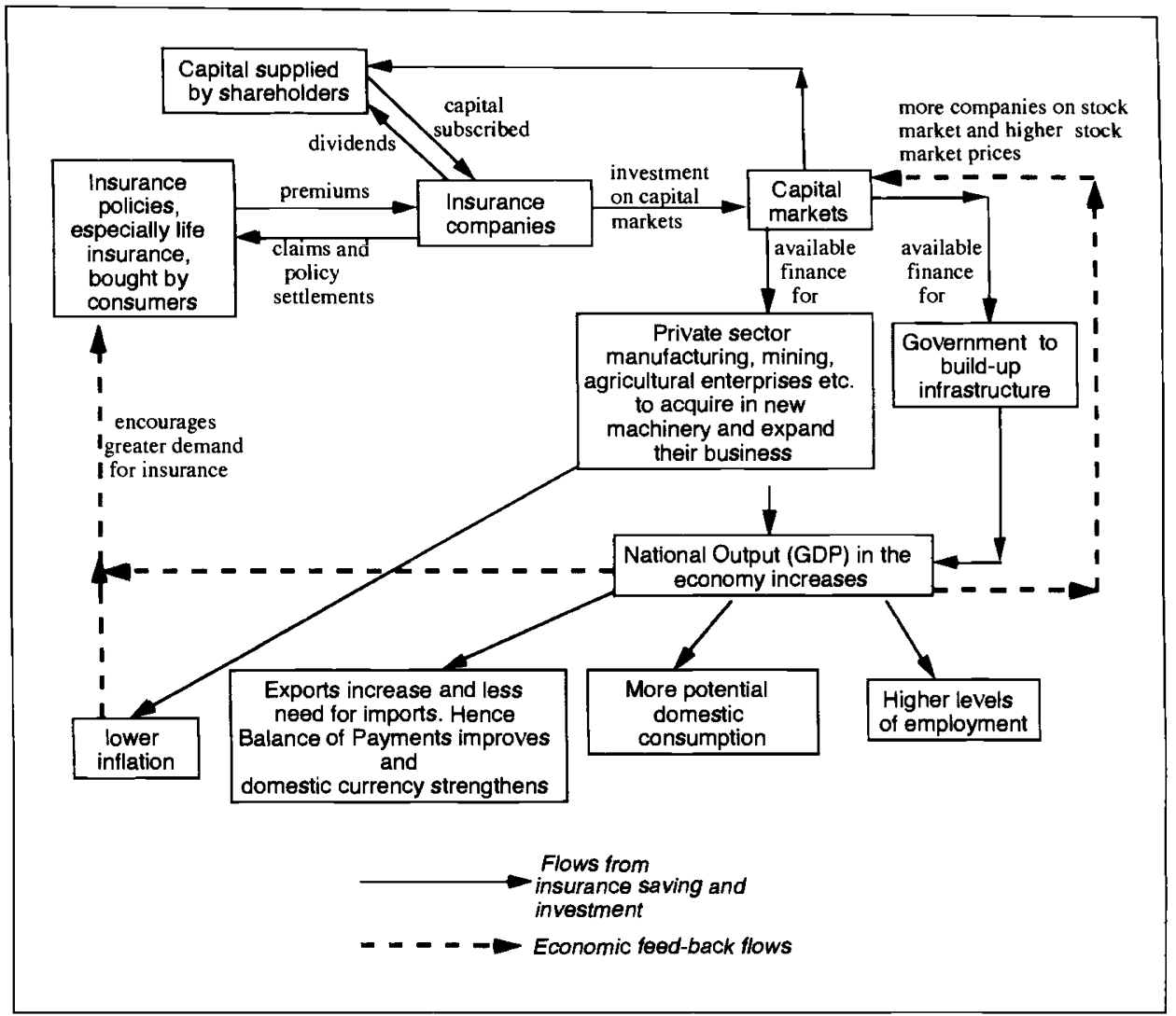

control. Clearly a balance needs to be struck between the level of domestic and foreign ownership within a country, a level which will depend on the political preferences and indeed on the psychology of the nation itself. But it should be noted that foreign manufacturing and commercial companies investing in a country like to see the existence of a well-developed capital market, since they themselves will wish over time to raise capital on this market to help finance the future growth of their local operations.

Figure 2 gives a graphical representation of the role that insurance companies play in the mobilisation of saving and through the investment of this saving in the capital market its impact on the wider macro-economy. It is obvious that since the insurance industry is only a part of the economy, the insurance industry itself will be more affected by the economic environment than the economy itself will be affected by the activities of the insurance industry. More particularly, the general standard of living in a country will have a major effect on the level of demand for insurance, while high inflation has a major disincentive effect on all saving, including saving through life insurance. 


\section{Dual role in the risk transfer-capital nexus}

It is clear from the above that the insurance sector as a whole plays a key economic role within the risk transfer-capital market nexus. On the one hand, insurance and reinsurance companies accept some of the risks from the economic activities of corporations, including risks arising from the financial intermediation roles of banks and other financial institutions. In supplying these risk transfer facilities, insurance and reinsurance companies need to hold capital to absorb the risks that they accept. Even if there were no regulatory requirement to hold capital, insurance and reinsurance companies would hold capital for precautionary purposes. The holding of capital imposes a cost on an insurance company or reinsurance company: its marginal cost being the differential between the cost of capital and the rate of return that the insurance company can earn on the investment of those capital funds. However, the capital held across the economy as a whole is less than if there were no insurance companies. This efficiency of capital rests on the fact that capital markets are not perfect, viz. it is not possible to raise additional equity capital instantaneously at the market rate of interest. Theoretically, the optimal way to finance risk is a call option on the equity capital market (i.e. ' just -in-time capital'), but this is not feasible in practice to any significant degree; however, there is likely to be some move in this direction in the future with the introduction of new ATR (Alternative Risk Transfer) products which can also be used by insurance and reinsurance companies for their own risk financing, but this will require more flexibility within national insurance regulations on what constitutes acceptable capital adequacy standards.

Figure 3: The role of the insurance sector in the risk transfer/capital market nexus

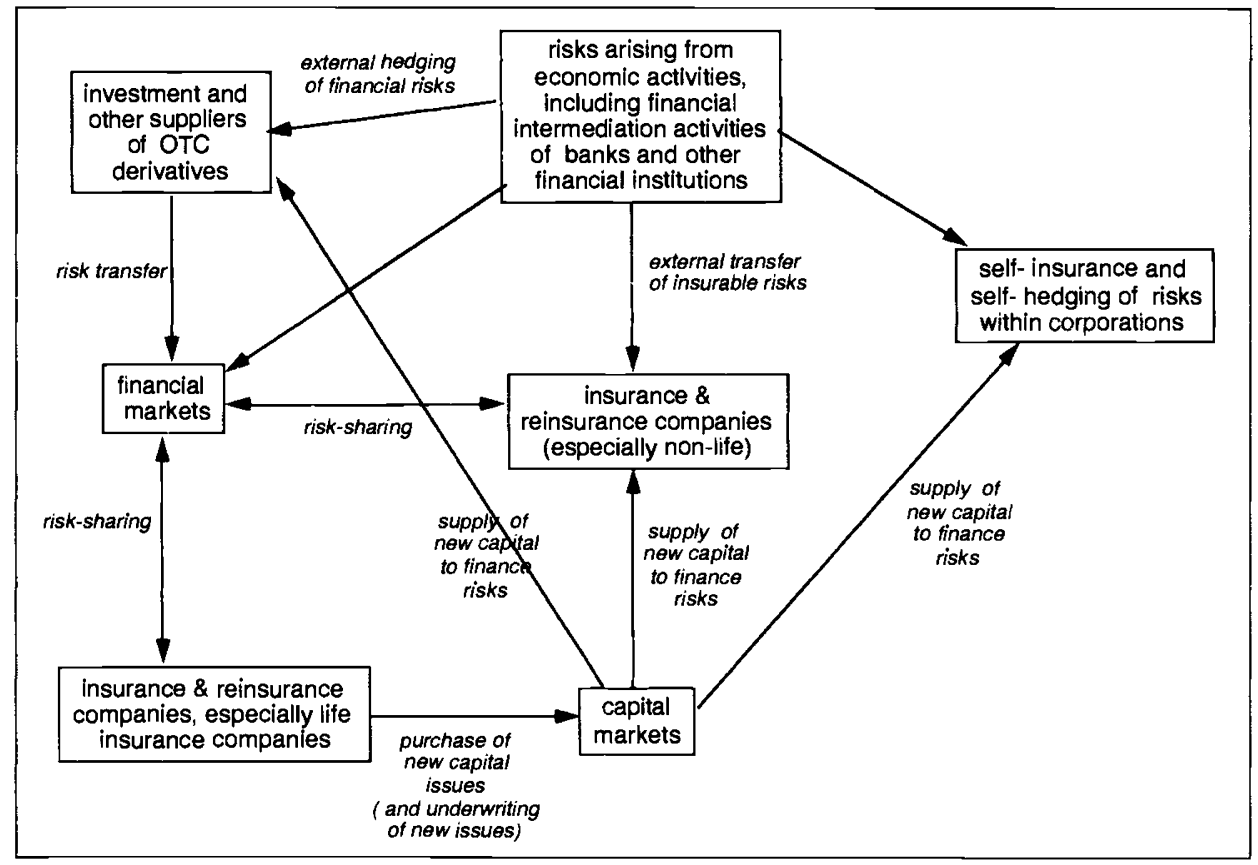


But, as we have noted above, the insurance sector, especially life insurance, also plays an important role in the supply of funds to the capital market. In many countries of the world, life insurance companies, together with pension funds and other long-term investors, are now the major owners of shares and bonds. Hence, life insurance companies through mobilising long-term saving ensure a source of supply for new capital issues which replenish capital markets. Hence, the insurance sector contributes at both ends of the risk transfer - capital market nexus.

\section{REFERENCES}

CARTER, R.L. and DICKINSON, G.M. (1992), Obstacles to the Liberalisation of Trade in Insurance. Trade Policy Research Centre. London: Harvester Wheatsheaf.

DICKINSON, G.M (1997): "Integrating Insurance and Hedging Decisions into the Overall Risk Management of the Firm", Singapore International Insurance and Actuarial Journal, No. 1 pp. 161-173.

DOHERTY, N. (1997) "Insurance Markets and Climate Change", The Geneva Papers on Risk and Insurance, 83, , pp. 223-237.

GIARINI, O and W. R.STAHEL (1993), The Limits of Certainty: Risks facing the new Service Economy. 2nd Edition. Dordrecht, Netherlands: Kluwer Academic Publishers.

GOLLIER, C. and KESSLER, D (1994), “Limites de l'Assurabilite” Risques, 17,pp. 89-92.

KIELHOLZ, W. and DURRER, A. (1997); "Insurance Derivatives and Securitization: New Hedging Perspectives for the US cat Insurance Market”, The Geneva Papers on Risk and Insurance, 82, pp. 3-16.

KUNREUTHER, H. (1997) "Rethinking Society's Management of Catastrophic Risks", The Geneva Papers on Risk and Insurance, 83, pp. 151-176.

OECD (1993), Policy Issues in Insurance, Paris.

SKIPPER, H. D. (1997): "The Role of Insurance in Development: an Economic Perspective" Singapore International Insurance and Actuarial Journal, Vol 1, No. 1, pp 1-17.

SHAVELL, S (1979), "On Moral Hazard and Insurance”, Quarterly Journal of Economics. pp. 541562.

SMITH,R.E., CANELO, E.O. and DIO, A.M.(1997), "Reinventing Reinsurance using the Capital Markets", The Geneva Papers on Risk and Insurance, 82, pp. 26-37. 